\begin{tabular}{|l|l|l|}
\hline Received : Maret 2021 & Accepted: Juni 2021 & Published : Juli 2021 \\
\hline
\end{tabular}

\title{
Analisis Pemahaman Tentang Pengelolaan Sampah Komunitas Bank Sampah Induk Surabaya (BSIS) melalui Transfer Knowledge
}

\author{
Ummi Fadlilah K..$^{*}$, Vivin Setiani ${ }^{2}$ \\ ${ }^{1}$ Jurusan Perencanaan Wilayah dan Kota, Institut Teknologi Sepuluh Nopember (ITS) Surabaya \\ ${ }_{2}^{2}$ Program Studi Teknik Pengolahan Limbah, Jurusan Teknik Permesinan Kapal,Politeknik Perkapalan Negeri
}

Surabaya

fa.ummi99@gmail.com

\begin{abstract}
Surabaya is an urban area that has good waste management techniques, but community participation is still not optimal. One of the participants who plays an important role in directing the attitude of the people of Surabaya to care about the environment is the Bank Sampah Induk Surabaya (BSIS) community. In this study, waste management socialization activities were carried out to increase the knowledge of the BSIS community. Measuring the level of knowledge of the participants after getting socialization of waste management have been used the quantitative method of Paired Sample t-test. Test the effect of education level, age, gender and occupation have been used the Pearson correlation method. The result of this research was that socialization has been a positive effect in increasing knowledge of waste management. The level of education influenced the understanding of good waste management. On the other hand, gender, occupation and age of the BSIS community did not affect the understanding of good waste management
\end{abstract}

Keywords: socialization, waste management, knowledge, education

\begin{abstract}
Abstrak
Surabaya merupakan daerah perkotaan yang memiliki teknik pengelolaan sampah yang baik, namun partisipasi masyarakat dalam masih belum maksimal. Salah satu partisipan yang berperan penting dalam mengarahkan sikap masyarakat Surabaya untuk peduli lingkungan adalah komunitas Bank Sampah Induk Surabaya (BSIS). Pada penelitian ini dilakukan kegiatan sosialisasi pengelolaan sampah untuk meningkatkan pengetahuan komunitas BSIS. Pengukuran tingkat pengetahuan peserta setelah mendapatkan sosialiasi pengelolaan sampah menggunakan metode kuantitaif Uji Paired Sample t-test. Uji pengaruh tingkat pendidikan, usia, gender dan pekerjaan menggunakan metode korelasi pearson. Hasil penelitian ini adalah sosialisasi memberikan pengaruh positif dalam meningkatkan pengetahuan pengelolaan sampah. Tingkat pendidikan berpengaruh dalam pemahaman pengelolaan sampah yang baik. Sebaliknya gender, pekerjaan dan usia dari komunitas BSIS tidak berpengaruh dalam pemahaman pengelolaan sampah yang baik.
\end{abstract}

Kata Kunci: sosialiasi, pengelolaan sampah, pengetahuan, pendidikan

\section{Pendahuluan}

Menurut Kementerian Lingkungan Hidup dan Kehutanan Republik Indonesia, pada tahun 2017-2018 timbulan sampah Kota Surabaya sebesar 2.790,89 ton/hari dengan jumlah penduduk 3.074.883 jiwa [21], sedangkan timbulan sampah tahun 2011 Kota Surabaya sebesar 1.200 ton/hari, dengan jumlah penduduk 3.024.321 jiwa [14]. Pertambahan jumlah penduduk diperkotaan semakin tinggi berbanding lurus dengan timbulan sampah. Beberapa aspek yang 
mempengaruhi timbulan sampah di perkotaan terdiri dari pertumbuhan penduduk, urbanisasi, dan perubahan gaya hidup yang terjadi di masyarakat [6].

Pada penelitian [25] jumlah penduduk di Indonesia (220.000.000 jiwa), maka sampah plastik yang tertimbun dapat mencapai 26.500 ton per hari. Menurut Kementerian Lingkungan Hidup dan Kehutanan Republik Indonesia pada tahun 2017-2018 [21], komposisi timbulan sampah Kota Surabaya antara lain : sampah sisa makanan 54,31\%; sampah kayu dan ranting daun 1,615; sampah kertas 14,63\%; sampah plastik 19,44\%; sampah logam 0,48\%; sampah kain tekstil 1,47\%; sampah karet kulit 2,33\%; sampah kaca $1,12 \%$, dan sampah jenis lainnya $4,61 \%$. Sumber timbulan sampah terbesar yaitu sampah rumah tangga sebesar 43,45\%. Sampah menjadi permasalahan jika kemudian tidak diolah dengan baik dan tidak dimanfaatkan. Pengolahan sampah yang tidak efektif akan menimbulkan masalah pada kesehatan manusia dan kerusakan alam [15] Permasalahan sampah dapat diatasi dengan menerapkan prinsip Reduce, Reuse dan Recycle (3R ) [26].

Menurut [19], Tempat Pemrosesan Akhir (TPA) Benowo Surabaya telah memanfaatkan sampah organik menjadi energi listrik. Hal ini menyebabkan pengelolaan sampah di Surabaya mendapatkan penghargaan dari dunia Internasional melalui kunjungan Delegasi United Nations Environment Programme (UNEP). Salah satu aspek yang mempengaruhi tingkat efektivitas pengelolaan sampah adalah partisipasi masyarakat dalam memilah sampah berdasarkan jenisnya [12]. Menurut hasil penelitian [27] menunjukkan bahwa sikap pemilahan sampah berhubungan dengan kepedulian lingkungan. Sosialisasi pengelolaan sampah akan memberi dampak terhadap peningkatan kesadaran lingkungan, pengetahuan, skill, nilai, dan pengalaman dalam meningkatkan kepedulian lingkungan dan mengatasi permasalahan pengelolaan sampah [27]. Oleh karena itu, dalam penelitian ini, sosialisasi pengelolaan sampah dibutuhkan untuk meningkatkan pengetahuan masyarakat.

Bank Sampah Induk Surabaya (BSIS) merupakan salah satu pihak kader lingkungan di Surabaya yang berperan penting dalam 3R sampah. BSIS merupakan bank sampah pusat di Kota Surabaya yang menampung sampah anorganik dari hasil pemilahan sampah oleh masyarakat Surabaya. Menurut hasil penelitian [1], BSIS juga berkontribusi dalam membimbing masyarakat untuk berpartisipasi dalam memilah sampah berdasarkan sampah organik dan anorganik. Berdasarkan hasil wawancara, (2020) komunitas BSIS belum memahami konsep ilmiah dari sampah anorganik dan organik. Oleh karena itu, pada penelitian ini dilakukan sosialisasi pengelolaan sampah berbasis 3R berdasarkan jenis sampah organik dan anorganik untuk meningkatkan pengetahuan komunitas BSIS.

\section{Metoda Penelitian \\ 2.1. Penentuan sampel}

Sampel dalam penelitian ini adalah komunitas BSIS sebagai peserta sosialisasi pengelolaan sampah. Hal ini dikarenakan BSIS merupakan pihak yang berperan aktif dalam menampung hasil pemilahan sampah dari masyarakat Surabaya. Adapun jumlah sampel penelitian ini sebanyak 25 orang dari 40 orang yang masih aktif dan tergabung dalam komunitas bank sampah. Berikut karakteristik jumlah responden berdasarkan jenis kelamin, range usia, dan jenjang pendidikan.

Tabel 1. Karakteristik Responden Berdasarkan Jenis Kelamin

\begin{tabular}{|c|c|c|}
\hline Jenis Kelamin & $\mathbf{N}$ & $(\%)$ \\
\hline Laki-laki & 7 & 28 \\
\hline Perempuan & 18 & 72 \\
\hline
\end{tabular}

Berdasarkan distribusi karakteristik resnponden diatas, jenis kelamin yang paling banyak berpartisipasi dalam kegiatan sosialisasi pengelolaan sampah adalah perempuan, yakni sebesar $72 \%$.

Tabel 2. Karakteristik Responden Berdasarkan Usia

\begin{tabular}{lcl}
\hline Range Usia & N & $(\%)$ \\
\hline$<30$ & 5 & 20
\end{tabular}




\begin{tabular}{lrr}
$30-40$ & 11 & 44 \\
$>40$ & 9 & 36 \\
\hline
\end{tabular}

Berdasarkan distribusi karakteristik resnponden diatas, usia yang paling banyak berpartisipasi dalam kegiatan sosialisasi pengelolaan sampah adalah pada range 30-40, yakni sebesar $44 \%$. Sementara usia <30 dan $>40$ masing-masing persentasenya adalah $20 \%$ dan $36 \%$.

Tabel 3. Karakteristik Responden Berdasarkan Jenjang

\begin{tabular}{lrl}
\multicolumn{3}{c}{ Pendidikan } \\
\hline Range Usia & N & $(\boldsymbol{\%})$ \\
\hline SMP & 6 & 24 \\
SMA & 10 & 40 \\
S1 & 4 & 16 \\
S2 & 5 & 20 \\
\hline
\end{tabular}

Berdasarkan distribusi karakteristik resnponden diatas, jenjang pendidikan yang paling banyak berpartisipasi dalam kegiatan sosialisasi pengelolaan sampah adalah pada jenjang pendidikan SMA, yakni sebesar $40 \%$. Sementara jenjang pendidikan SMP, S1 dan S2 masing-masing persentasenya adalah $24 \%$, dan $16 \%$, dan $20 \%$.

\subsection{Persiapan sosialisasi pengelolaan sampah \\ Tahap ini melakukan persiapan} sosialisasi berupa persiapan angket kuisioner dan materi pengelolaan sampah. Sosialisasi ini memberikan pengetahuan kepada komunitas bank sampah terkait karakteristik sampah, metode-metode pengolahan sampah, best practices pengelolaan sampah, serta tutorial pengolahan sampah.

\subsection{Pelaksanaan sosialisasi pengelolaan sampah}

Sebelum memulai acara sosialisasi pengelolaan sampah, dilakukan penyebaran kuisioner tentang pengetahuan pengelolaan sampah. Kemudian dilakukan sosialisasi pengelolaan sampah. Selanjutnya diakhiri dengan penyebaran kuisioner tentang pengetahuan pengelolaan sampah setelah mendapatkan sosialisasi pengelolaan sampah.

\subsection{Pengukuran tingkat pengelolaan sampah}

Pengukuran tingkat pengetahuan peserta setelah mendapatkan sosialiasi pengelolaan sampah dengan menggunakan metode kuantitaif Uji Paired Sample t-test dan pengaruh tingkat pendidikan, usia, gender dan pekerjaan menggunakan metode korelasi pearson.

\subsubsection{Uji Paired Sample t-test}

Analisis tingkat pemahaman peserta setelah dan sebelum mengikuti sosialisasi dengan adalah kuantitatif Uji Paired Sample ttest. Uji ini dipilih karena dalam penelitian objek penelitian yakni peserta pelatihan dikenai dua perlakuan berbeda sehingga menghasilkan dua macam sampel [11]. Adapun variabel dari penelitian ini yakni nilai peserta sebelum diadakan sosialisasi pengelolaan sampah (Score Pre Test) dan nilai peserta setelah diadakan sosialisasi pengelolaan sampah (Score Post Test). Berikut rumus perhitungan Uji Paired Sample t-test:

$$
\text { thitung }=\frac{D}{\frac{S D}{\sqrt{n}}}
$$

Dimana:

$\mathrm{t} \quad=$ nilai $\mathrm{t}$ hitung

$\bar{D}=$ rata-rata selisih score pre dan post test

$\mathrm{SD}=$ standar deviasi dari nilai $\bar{D}$

$\mathrm{n} \quad=$ jumlah sampel

Hipotesis

H0 : $\mu$ setelah $=\mu$ sebelum

Ada beberapa persyaratan yang harus dipenuhi sebelum uji $\mathrm{t}$ dilakukan [7]. Persyaratan tersebut adalah data penelitian harus berdistribusi normal. Pengujian normalitas data menggunakan Uji Shapiro Wilk. Penggunaan uji ini digunakan untuk sampel kecil, yakni kurang dari 50 [7]. Sampel dalam penelitian terdiri dari 25 peserta. Pengujian normalitas menggunakan aplikasi statistik yakni IBM SPSS Statistics 21 dengan ketentuan hasilnya adalah nilai sig. lebih besar dari 0,05 maka dikatakan berdistribusi normal [20]. Pedoman dalam pengambilan keputusan 
hasil uji parired sample t-test adalah berdasarkan nilai signifikansi. Jika nilai sig. (2-tailed) kurang dari 0,5 maka $\mathrm{H}_{\mathrm{o}}$ ditolak begitupun sebaliknya [20].

\subsubsection{Analisis Korelasi pearson}

Pengukuran hubungan jenis kelamin, pekerjaan, dan tingkat pendidikan dengan tingkat pemahaman peserta menggunakan metode korelasi untuk mengetahui apakah ada hubungan antara usia, jenis kelamin, pekerjaan, dan tingkat pendidikan dengan tingkat pemahaman peserta sosialisasi. Analisis korelasi yang digunakan adalah korelasi pearson. Korelasi pearson untuk mengukur hubungan variabel bebas (X) dengan variabel terikat (Y) [4]. Koefisien korelasi menyatakan derajat hubungan antara variabel bebas dengan variabel terikat [22]. Besarnya koefisien korelasi pada nilai $-1<0<$ 1. Semakin mendekati nilai 1 , maka hubungan antara variabel bebas dengan variabel terikat sangat kuat [23]. Pengambilan keputusan dalam Analisis korelasi pearson dapat dilihat dari nilai signifikansi sig.(2-tailed). Bila besaran nilai sig. (2-tailed) $<0,05$ maka terdapat korelasi antara variabel bebas dengan variabel terikat.

\section{Hasil Penelitian}

\subsection{Analisis Tingkat Pemahaman tentang} Pengelolaan Sampah

Hasil pengujian

normalitas

menggunakan aplikasi statistik menunjukkan nilai sig. Shapiro Wilk dari variabel score post test dan pre test lebih besar dari 0,05 yakni 0,054 dan 0,263 . Nilai tersebut berarti bahwa data score post test dan pre test peserta sosialisasi berdistribusi normal sehingga bisa dilanjutkan ke analisis paired sample t-test. Adapun data dalam penelitian ini sebegai berikut:

Tabel 5. Score Pre Test dan Post Test Peserta Sosialisasi

\begin{tabular}{ccc}
\multicolumn{3}{c}{ Pengelolaan Sampah } \\
\hline No & $\begin{array}{c}\text { Score } \\
\text { Pre }\end{array}$ & $\begin{array}{c}\text { Score } \\
\text { Post }\end{array}$ \\
& Test & Test \\
\hline 1 & 64 & 100 \\
2 & 43 & 83
\end{tabular}

\begin{tabular}{|c|c|c|}
\hline No & $\begin{array}{c}\text { Score } \\
\text { Pre } \\
\text { Test }\end{array}$ & $\begin{array}{c}\text { Score } \\
\text { Post } \\
\text { Test }\end{array}$ \\
\hline 4 & 37 & 90 \\
\hline 5 & 47 & 90 \\
\hline 6 & 61 & 88 \\
\hline 7 & 57 & 100 \\
\hline 8 & 71 & 93 \\
\hline 9 & 49 & 39 \\
\hline 10 & 49 & 93 \\
\hline 11 & 59 & 100 \\
\hline 12 & 59 & 93 \\
\hline 13 & 59 & 100 \\
\hline 14 & 71 & 88 \\
\hline 15 & 68 & 100 \\
\hline 16 & 49 & 100 \\
\hline 17 & 54 & 100 \\
\hline 18 & 66 & 100 \\
\hline 19 & 47 & 100 \\
\hline 20 & 29 & 100 \\
\hline 21 & 59 & 71 \\
\hline 22 & 59 & 71 \\
\hline 23 & 71 & 71 \\
\hline 24 & 49 & 68 \\
\hline 25 & 68 & 68 \\
\hline
\end{tabular}

Rumus hipotesis penelitian adalah $\mathrm{H}_{\mathrm{o}}$ : Tidak ada perbedaan rata-rata antara score sebelum dan sesudah diadakannya sosialisasi pengelolaan sampah pada komunitas BSIS. Sementara $\mathrm{H}_{1}$ : Ada perbedaan rata-rata antara score sebelum dan sesudah diadakannya sosialisasi pengelolaan sampah. Hasil analisis paired sample t-test sebagai berikut:

Tabel 4. Output Nilai Rata-Rata Sampel Berpasangan

\begin{tabular}{rlrrrr}
\hline \multicolumn{2}{c}{ Descriptions } & Mean & N & $\begin{array}{c}\text { Std. } \\
\text { Deviation }\end{array}$ & $\begin{array}{c}\text { Std. } \\
\text { Error } \\
\text { Mean }\end{array}$ \\
\hline \multirow{2}{*}{ Pair 1 1 } & Score Pre & 55.52 & 25 & 11.147 & 2.229 \\
& Scor ePost & 87.6000 & 25 & 15.31339 & 3.06268 \\
\hline
\end{tabular}

Hasil dari output diatas didapatkan melalui proses perhitungan sebagai berikut:

$\bar{X}=\frac{\sum_{i=1}^{n} X i}{n}=\frac{1388}{25}=55,2$

$S=\sqrt{\frac{1}{1-n} \sum(X i-\bar{X})^{2}}=\sqrt{124.26}=11,147 \ldots$ 
$S E=\frac{S}{\sqrt{n}}=\frac{11.147}{\sqrt{25}}=2.229$

Perhitungan dari persamaan (1) (2) dan (3) merupakan salah satu contoh proses untuk mendapatkan nilai mean, standar deviasi, dan standar error mean dari score pre test. Rumus perhitungan tersebut juga berlaku untuk menghitung nilai mean, standar deviasi, dan standar error mean dari score post test.

Berdasarkan output nilai rata-rata sampel berpasangan, terlihat bahwa nilai mean score post test lebih besar dari nilai mean score pre test. Hal ini menunjukkan bahwa secara deskriptif terdapat perbedaan rata-rata score sebelum dan setelah sosialisasi pengelolaan sampah (Tabel 2).

Tabel 6. Paired Samples Correlations

\begin{tabular}{lcccc}
\hline \multicolumn{2}{c}{ Descriptions } & N & Correlation & Sig. \\
\hline \multirow{2}{*}{ Pair 1 } & ScorePre & 25 & .909 & .024 \\
& ScorePost & & & \\
\hline
\end{tabular}

Output paired samples correlations menunjukkan hasil korelasi atau hubungan antara kedua variabel pre tes dan post tes. Berdasarkan output diatas, diketahui bahwa nilai koefisien korelasi sebesar 0,909 (Tabel 3). Hal ini berarti terdapat hubungan yang kuat antara score sebelum dan setelah peserta mendapatkan ilmu mengenai pengelolaan sampah.

Tabel 7. Paired Samples Test

\begin{tabular}{ccccc}
\multicolumn{2}{c}{ Descriptions } & t & Df & Sig. (2-tailed) \\
\hline \multirow{2}{*}{ Pair 1 } & $\begin{array}{l}\text { ScorePre - } \\
\text { ScorePost }\end{array}$ & -8.373 & 24 & .000 \\
\hline
\end{tabular}

Ouput ketiga merupakan output yang terpenting, karena pada bagian ketiga inilah akan menemukan jawaban atas apa yang menjadi hipotesis dalam penelitian ini yakni mengenai ada tidaknya perbedaan pada kemampuan peserta dalam memahami ilmu yang didapatkan setelah sosialisasi pengelolaan sampah. Adapun dari hasil paired sample test menunjukkan nilai sig. (2-tailed) sebesar 0,000 (Tabel 4). Nilai tersebut lebih kecil dari 0,05 yang berarti bahwa ada perbedaan rata-rata antara score sebelum dan sesudah diadakannya sosialisasi pengelolaan sampah pada komunitas BSIS. Hasil kegiatan sosialiasi pengelolaan sampah dapat meningkatkan pengetahuan komunitas BSIS dalam mengelola sampah.

Menurut hasil penelitian [16] menunjukkan bahwa salah satu hasil kegiatan sosialisasi pengelolaan sampah adalah masyarakat dapat berpartisipasi dalam menerapkan 3R di daerahnya. Selain itu, menurut [2] peningkatan pengetahuan terjadi setelah dilakukan sosialisasi dan dapat memberikan energi positif terhadap masyarakat dalam mengelola sampah. Di lain pihak, hasil penelitian [17], [8] dan [18] menyatakan bahwa pengetahuan seseorang tidak berpengaruh signifikan terhadap perilaku pengelolaan sampah. Hal ini disebabkan karena perilaku dasar pengelolaan sampah tergantung dari kesadaran masyarakat [8]. Selain itu, menurut [18] masyarakat yang memiliki pengetahuan baik namun memiliki sikap pengelolaan sampah yang tidak baik dikarenakan tingkat kesadaran masyarakat sangat minim.

3.2. Analisis Pengaruh Gender, Jenis Pekerjaan dan Tingkat Pendidikan Responden terhadap Tingkat Pemahaman tentang Pengelolaan Sampah

Analisis korelasi pearson dalam penelitian ini bertujuan untuk mengetahui apakah terdapat hubungan mengenai tingkat pemahaman peserta setelah mengikuti sosialiasi pengelolaan sampah dengan karakteristik peserta berdasarkan usia, jenis kelamin, pekerjaan, dan pendidikan terkahir. Variabel terikat dalam penelitian ini adalah variabel nilai test setelah peserta mendapatkan ilmu mengenai pengelolaan sampah. Sementara variabel bebasnya adalah usia, jenis kelamin, pekerjaan, dan pendidikan terkahir. Analisis korelasi diolah menggunakan aplikasi statistik. Pengolahan menggunakan software 
IBM SPSS Statistics 21 ini melalui beberapa proses tahapan sebagai berikut:

1. Pada tahap pertama, data diinput dalam excel. Data tersebut terdiri dari nilai post test sebagai variabel dependen dan data jenis kelamin (gender), pekerjaan, jenjang pendidikan, dan usia merupakan variabel independen

2. Data gender diubah dikonversi menjadi skala ordinal, dimana laki-laki $=1$ dan perempuan $=2$. Kemudian data pekerjaan juga dikonversi menjadi ibu rumah tangga $=1$, PNS $=2$, karyawan swasta $=3$. Data jenjang pendidikan dan usia juga dikonversi dalam skala ordinal, dimana untuk data jenjang pendidikan SMP $=1$, $\mathrm{SMA}=2, \mathrm{~S} 1=3$, dan $\mathrm{S} 2=4$. Sedangkan untuk data usia adalah $\angle 30=1,30-40=2$, dan $>40=3$.

3. Setelah data dikonversi kemudian diproses menggunakan software IBM SPSS Statistics 21 dengan meilih menu correlate ? bivariate ? centang box Pearson pada menu Correlation Coefficients.

Berikut merupakan output analisis korelasi person.

Tabel 8 Ouput Analisis Korelasi Pearson

\begin{tabular}{|c|c|c|c|c|c|c|}
\hline & & nilai_test & gender & pekerjaan & $\begin{array}{l}\text { Pendidi- } \\
\text { kan }\end{array}$ & usia \\
\hline \multirow{3}{*}{$\begin{array}{l}\text { nilai_ } \\
\text { test }\end{array}$} & Pearson & 1 & .044 & .108 & $.465^{*}$ & .056 \\
\hline & $\begin{array}{l}\text { Correlation } \\
\text { Sig. }(2- \\
\text { tailed) }\end{array}$ & & .835 & .606 & .019 & .791 \\
\hline & $\mathrm{N}$ & 25 & 25 & 25 & 25 & 25 \\
\hline
\end{tabular}

Berdasarkan hasil analisis korelasi pearson, variabel bebas yang memiliki korelasi dengan nilai test peserta adalah pendidikan terakhir. Hal ini ditunjukkan dengan nilai sig. (2-tailed) kurang dari 0,05 (Tabel 5). Dengan demikian dapat diartikan bahwa untuk mengoptimalkan pemahaman peserta sosialisasi perlu mempertimbangkan tingkat pendidikan terakhir peserta. Hal ini dikarenakan semakin tinggi pendidikan maka semakin tinggi tingkat pemahaman peserta dalam menerima ilmu-ilmu yang diberikan saat sosialisasi. Tingkat pemahaman dalam konteks penelitian ini diintepretasikan dengan nilai akhir peserta setelah mengikuti sosialisasi pengelolaan sampah (score post-test). Pendidikan merupakan proses dalam mendapatkan pemahaman dan pengetahuan, pengalaman serta peduli lingkungan dengan metode tertentu [5]. Dengan banyaknya peserta yang mamahami teori dan praktek pengelolaan sampah maka akan berdampak pada penurunan produksi sampah khusunya di sekitar tempat tinggal peserta. Semakin tinggi tingkat pendidikan masyarakat maka akan semakin tinggi pengetahuan masyarakat dalam mengolah sampahnya [13]. Hal ini sebanding dengan hasil penelitian [10]; [8] ; [9] dan [24]. Salah satu aspek yang mempengaruhi pengelolaan sampah terdiri dari tingkat pendidikan, tingkat pengembangan teknologi, teknik pengelolaan sampah, penerapan kebersihan, regulasi tentang persampahan dan penegakan hukum [8].

\section{Kesimpulan}

Setelah melakukan penelitian dapat disimpulkan bahwa sosialisasi pengelolaan sampah merupakan kegiatan transfer knowledge dari akademisi kepada komunitas BSIS di Kota Surabaya. Kegiatan sosialisasi ini memberikan dampak positif bagi peningkatan pengetahuan dalam pengelolaan sampah sehingga dampak berkelanjutan pada pengurangan timbulan sampah organik dan anorganik pada skala rumah tangga. Selain itu, tingkat pendidikan komunitas BSIS berpengaruh terhadapa tingkat pemahaman pengelolaan sampah. Namun, jenis kelamin, usia dan pekerjaan dari komunitas BSIS tidak berpengaruh dalam pemahaman pengelolaan sampah.

\section{Saran}

Pada penelitian ini, sosialisasi dilakukan selama 1 bulan, sehingga pengetahuan komunitas BSIS dalam mengelola sampah tidak sampai mendalam. Untuk penelitian selanjutnya sebaiknya sosialisasi yang dilakukan lebih lama dan lebih banyak 
frekuensinya dalam memberikan latihan atau praktek pengelolaan sampah agar terbiasa dengan kegiatan tersebut $\mathrm{Hal}$ ini didukung oleh hasil penelitian [3] bahwa pemahaman suatu proses membutuhkan pembelajaran dengan habituasi yang tidak singkat.

\section{Ucapan Terima Kasih}

Penulis mengucapkan terima kasih kepada Direktorat Riset dan Pengabdian Masyarakat (DRPM) ITS dan Pusat Kajian Potensi Daerah dan Pemberdayaan Masyarakat (PDPM) yang telah memberikan pendanaan kegiatan ini melalui No: 1067/PKS/ITS/2020, tanggal 02 April 2020. Tak lupa penulis juga menyampaikan apresiasi yang tinggi pada mitra dalam kegiatan sosialisasi pengelolaan Sampah yakni rekan-rekan dari Komunitas BSIS, dan juga kolega Departemen Perencanaan Wilayah dan Kota, Fakultas Teknik Sipil, Perencanaan Dan Kebumian (FTSPK), serta Teknik Pengolahan Limbah/ Politeknik Perkapalan Negeri Surabaya yang telah memberikan sumbangsih pemikiran selama kegiatan berlangsung.

\section{Daftar Pustaka}

[1] A. Elga,'Analisis Perilaku Pemilahan Sampah di Kota Surabaya," Aspirasi: Jurnal Masalah-Masalah Sosial, Vol.10, No. 2,2019.

[2] Armi, and N. Mardhiah, 'Pengaruh Sosialisasi Pengelolaan Sampah Masyarakat Terhadap Perilaku Membuang Sampah Ke Sungai Di Desa Mideun Geudong Kecamatan Samalanga Kabupaten Bireun', Serambi Saintia Jurnal Sains dan Aplikasi, Vol. IV, No. 1, 2016.

[3] D. I. Candra, and Setian,''Habituation Behavior to Enhance Student Learning. Advances in Social Science, Education and Humanities Research," Proceedings of the 1st International Multidisciplinary Conference on Education, Technology, and Engineering (IMCETE), 2019.

[4] F. Zamal. Korelasi antara Pelatihan Teknis Perpajakan, Pengalaman dan Motivasi Pemeriksa Pajak dengan Kinerja Pemeriksa Pajak pada Kantor Pelayanan Pajak di Jakarta Barat, Jakarta: Skripsi. FAKULTAS
EKONOMI DAN ILMU SOSIAL UNIVERSITAS ISLAM NEGERI SYARIF HIDAYATULLAH, 2009.

[5] Gurdjita, 'Hubungan Antara Tingkat Pendidikan Formal Dan Sikap Warga Dengan Perilakunya Dalam Pemeliharaan Kebersihan Lingungan,' Jurnal Pendidikan \& Ilmu Pengetahuan, Vol. 4, No.2, pp. 5367, 2008.

[6] H. Diana, 'Kebijakan Pengelolaan Sampah Berbasis Masyarakat Sebagai Solusi Alternatif Green City di Kota Surabaya,', Jurnal Dinamika Governance FISIP UPN "Veteran" Jatim, Vol. 7, No. 1, pp. 95, 2017.

[7] H.Usman, and P. Setiadi Akbar, Pengantar Statistika, Jakarta: BUMI AKSARA, 2008

[8] Jumar, N. Fitriyah, and R. Kalalinggi,',Strategi Pengelolaan Sampah Rumah Tangga di Kelurahan Lok Bahu Kecamatan Sungai Kunjang Kota Samarinda,' Jurnal Administrative Reform, Vol. 2, No. 1, pp. 771-782, 2014.

[9] K. Ulli dan D.R. Jati, 'Pengaruh Aspek Pengetahuan Dan Pendidikan Masyarakat Tepi Sungai Kapuas Dalam Membuang Sampah,' Jurnal Vokasi Kesehatan, Vol. 4, No. 1, 2018.

[10] Krisnawati, T.O, Pengelolaan Sampah Domestik Masyarakat dan Jumlah Titik Sampah di Tepi Sungai Code Wilayah Gondolayu sampai Ringroad Utara Yogyakarta, Yogyakarta : Skripsi. UNIVERSITAS KRISTEN DUTA WACANA, 2012

[11] K. Denny, ''Uji T Berpasangan (Paired TTest)," Vienna (AT) : FOUNDATION FOR STATISTICAL COMPUTING, 2008.

[12] Aryenti, “' Peningkatan Partisipasi Masyarakat Dalam Pengelolaan Sampah dengan Cara Reduce, Reuse, Dan Recycle Di Lingkungan Permukiman Ditinjau Segi Sosial Ekonomi Masyarakat, " Jurnal Permukiman, Vol 6, No.2, pp. 75-83, 2010.

[13] Mifbakhuddin, 'Gambaran Pengelolaan Sampah Rumah Tangga Tinjauan Aspek Pendidikan, Pengetahuan, dan $\begin{array}{llllll}\text { Pendapatanperkapita di RT } & 6 & \text { RW } & 1\end{array}$ Kelurahan Pedurungan Tengah Semarang,' Jurnal Kesehatan Masyarakat Indonesia, Vol. 6, No. 1, pp. 1-14, 2010. 
[14] R. Qonita. dan W. Herumurti, 'Pengolahan Sampah secara Pirolisis dengan Variasi Rasio Komposisi Sampah dan Jenis Plastik,' Jurnal Teknik ITS, Vol. 4, No. 1, pp. D27, 2015.

[15] R. Y. Puspita, Y.Trihadiningrum, E.S Pandebesie, and Y. Dhokhika, 'Perencanaan Fasilitas Pengolahan Sampah Rumah Tangga di Kecamatan Rungkut Kota Surabaya," Jurnal Teknik Pomits, Vol. 2, No. 1, 2013.

[16] Ruhmawati, , M. Karmini and D. Tjahjani P. , 'Peningkatan Pengetahuan Dan Sikap Kepala Keluarga Tentang Pengelolaan Sampah Melalui Pemberdayaan Keluarga di Kelurahan Tamansari Kota Bandung, ", Jurnal Kesehatan Lingkungan Indonesia, Vol.16, No.1, pp. 1-7. 2017.

[17] N.A. S. Saputra, and S.A Mulasari, 'Pengetahuan, Sikap, dan Perilaku Pengelolaan Sampah pada Karyawan di Kampus, " Kes Mas: Jurnal Kesehatan Masyarakat, Vol. 11, No. 1, pp. 22 -27, 2017.

[18] S. Novita dan S.A Mulasari, " Pengetahuan, Sikap Dan Pendidikan Dengan Perilaku Pengelolaan Sampah Di Kelurahan Bener Kecamatan Tegalrejo Yogyakarta,' Jurnal Medika Respati, Vol. 12, No. 2, 2017.

[19] Kementerian Lingkungan Hidup dan Kehutanan, " Siaran pers PPID", PPID KEMENTERIAN LINGKUNGAN HIDUP DAN KEHUTANAN, http://ppid.menlhk.go.id/siaran_pers/browse/ 1595 diakses tanggal 26 November 2020

[20] S. Santoso. Panduan Lengkap SPSS Versi 20 Edisi Revisi. Jakarta: ELEX MEDIA KOMPUTINDO.2014.

[21] SIPSN, "Sistem Informasi Pengelolaan Sampah Nasional," Diakses pada tanggal 2 Desember 2019: http://sipsn.menlhk.go.id/., 2018.

[22] S. Syofian. Statistik Parametrik untuk Penelitian Kualitatif. Jakarta: BUMI AKSARA. 2013.

[23] Sudjana. Metoda Statistika. Bandung. Tarsito. 2005.

[24] Sukerti, N.L Gede, I .M. Sudarma, I. M.; Pujaastawa, dan I.B.G Pujaastawa, 'Perilaku Masyarakat Dalam Pengelolaan Sampah Dan Faktor-Faktor Yang
Mempengaruhi Di Kecamatan Denpasar Timur Kota Denpasar,' Ecotrophic: Jurnal Ilmu Lingkungan, Vol. 11, No.2, pp.148155, 2017

[25] Susilo, G. B, 'Pembuatan Bahan Bakar dari Pirolisis Limbah Plastik Jenis Polietilen, Polistiren, dan Other. Journal Teknologi Technoscientia: Teknik Mesin, Institut Sains \& Teknologi AKPRIND Yogyakarta, Vol.8 No.2, 2016.

[26] Trihadiningrum, Yulinah. MDGs Sebentar Lagi Sanggupkah Kita Menghapus Kemiskinan di Dunia. Jakarta : PT. GRAMEDIA. 2010.

[27] Zakianis, Sabarinah., \& I. M. Djaja, 'The Importance of Waste Management Knowledge to Encourage Household WasteSorting Behaviour in Indonesia. International,', Journal of Waste Resources, Vol. 07, No.04, 2017. 